\title{
Reconsidering the Trend in \\ Incumbent Vote Percentages in House Elections
}

\author{
Jeffrey M. Stonecash
}

The rise in the vote percentage for House incumbents since 1946 has been a central concern in election studies. The presumed increase has prompted numerous attempts to explain it. The increase has also served as a basis for considerable commentary about change in the nature of contemporary politics and elections.

This analysis argues that the presumed increase is largely an artifact of the questionable decision to exclude uncontested elections. As the number of uncontested races declined from the $1950 \mathrm{~s}$ through the 1960s, adding in these districts created an apparent increase that arguably did not really occur. When all incumbent races are considered, the pattern over the last 50 years is one of no increase in the percentage of the vote received by incumbents.

\section{The Centrality of Vote Percentage Trends}

Over the last several decades, the percentage of the vote received by House incumbents has been central to studies of congressional elections. The increase in the average vote percentage from the 1950s to the $1970 \mathrm{~s}$ prompted concern about whether incumbents were able to exploit the political resources of campaign funds and the resources of office (mailings, travel to the district, or constituency work) to create higher visibility, discourage challengers, and boost their vote percentages. Did this in turn allow incumbents to reduce district competitiveness and perhaps shield themselves from some electoral pressures? Some interpreted this as the result of House members trying to make votes "personal" and less tied to votes on policy issues.

Given the concern this trend prompted, the crucial issue is what trend in vote percentages for House incumbents actually occurred. The argument of this analysis is that the finding of a post-WWII increase in incumbent vote percentages is questionable. The apparent trend was a product of questionable decisions about which cases to examine. The most important and dubious decision was to consider only contested elections. That decision interacted with changes in the number of uncontested elections over time, with the result that vote percentages appeared to rise, when in fact they did not. Elections did not become less competitive. Indeed, it is quite possible to argue that House elections since 1946 have become more competitive.

JEFFREY M. STONECASH is Professor of Political Science, Maxwell School, Syracuse University and Professor-in-Residence, the New York State Assembly.

The American Review of Politics, Vol. 24, Fall, 2003: 225-239

(C)2003 The American Review of Politics 
This paper first explains the development of the consensus about rising vote percentages, and then reviews the decisions made about how to handle data in these studies. The actual trends in election results are then presented.

\section{The Development of a Consensus about the Trend}

The focus on House Members' vote percentages emerged at a time when other studies were yielding evidence that American electoral behavior was undergoing fundamental change. Evidence was emerging that the power of party attachments in shaping voting behavior was declining. Aggregate level analyses indicated that in the decades prior to the 1960s, there had been a steady rise in ticket-splitting (Burnham 1965, 13-20). The partisan vote in House districts for House and presidential candidates was steadily diverging (Jones 1964, 465; Cummings 1966, 31-39; Burnham 1975, 428), such that presidential and House results were less connected. At the individual level, NES surveys found that identification with parties was declining (Converse 1976, 32 and 70), that partisan voting (someone identifying with a party and voting for candidates of that party) was declining and that split-ticket voting was increasing (Flanigan and Zingale 1979, 45-60). ${ }^{1}$

With such trends emerging, it was a logical step to see changes in voting for House incumbents as just another manifestation of the electoral changes underway. In the mid-1970s Mayhew published two studies that initiated a sustained focus on this issue. First, he found that from 1958 to 1972 the proportion of competitive (marginal) House races declined (Mayhew 1974a, 297-304). Second, he offered a possible explanation of this change. He argued that a party perspective was of little use in trying to understand member behavior and House elections (Mayhew 1974b, 27). He speculated that the most plausible explanation of this change was the increased resources that House members had available to them (Mayhew 1974a, 310-313). Perhaps most important, he offered a framework for seeing House candidates as autonomous and calculating actors trying to shape their electoral fortunes (Mayhew 1974b). The presumption that members sought to improve their reelection prospects was by no means new, but he coupled this with a clear view of how members could use the increased public resources available to them to achieve this objective. Fiorina reinforced this with a speculation that the more recent crop of members was different in that they cared more about winning reelection and catering to constituents than policy and the public interest (1977a, 179). Mayhew's argument about how to view House members and their activities quickly became central to attempts to explain election results (Brady, Cogan, and Fiorina 2000, 5).

Subsequent studies confirmed Mayhew's finding of declining competition. Some studies focused on changes in the percentage of marginal districts 
(Cover and Mayhew 1977, 63; Krehbiel and Wright 1983, 143), others focused on the average percentage of the vote won by incumbents over time (Born 1979, 813; Alford and Hibbing 1981, 1051; Garand and Gross 1984, 21; Jacobson 1987, 127), while Gross and Garand analyzed both (1984, 227 and 234). All concluded there were fewer marginal seats and that incumbents were winning larger percentages of the vote.

With such consistency of findings, the focus shifted to trying to explain how this effect was emerging and what might explain it. There were efforts to measure the "sophomore surge," or the gain in the first incumbency election (Cover 1977, 527-28; Cover and Mayhew 1977, 69-70; Born 1979, 81415; Collie 1981, 124), the "retirement slump," or the loss in party percentage of the vote when an incumbent retired (Cover and Mayhew 1977, 69-70; Payne 1980, 269-72), and the career electoral paths of members (Alford and Hibbing 1981, 1047-49).

The central issue was whether change was a result of shifts in electoral behavior, which incumbents had limited control over, or in the activities of incumbents, which they could control (Krehbiel and Wright 1983, 141). Those who focused on change in the electorate relied heavily on Burnham's $(1970 ; 1975)$ thesis of electorate disengagement from parties. Using his arguments as a guide, there were efforts to understand whether partisan defection was increasing and how much incumbents had been able to raise their name recognition (Abramowitz 1975; Cover 1977, 531-36; Ferejohn 1977, 169; Nelson 1978-79; Mann 1978; Campbell 1983; Krehbiel and Wright 1983). Others focused more on matters incumbents could specifically control. They examined the effects of redistricting (Tufte 1973; Ferejohn 1977, 167-68; Ansolabehere et al. 2000), legislator activities and interaction with constituents through mail and casework (Johannes 1977; Johannes and McAdams 1981; Fiorina 1981; McAdams and Johannes 1987 (and the literature they cite); Serra and Cover 1992; Serra 1994 [and the literature he cites]; Jacobson 2001, 21-100), how challengers and their quality matter (Krasno and Green 1988; Cox and Katz 1996; Levitt and Wolfram 1997), and the impact of campaign spending on electoral margins (Jacobson 1978; Abramowitz 1989; 1991, 48-52).

While there have been numerous attempts to explain rising vote percentages, it would be difficult to say that any definite source of the purported change has been identified. Though evidence about the ability of legislators to actively manipulate their electoral margins has been more circumstantial than causal, it is common for texts on congressional elections to present as conventional wisdom that incumbents have gradually increased their vote percentages since the 1950s and that the increase is due to the significant increases in political resources over the same time period (Jacobson 2001, 24-25). 


\section{Calculating Vote Percentages: Which Cases to Examine}

The bulk of this research has focused on the empirical trend in vote percentages. The central issue is whether an upward trend actually occurred. Assuming that election results are recorded correctly, ${ }^{2}$ the issue is whether the initial methodological decisions are appropriate. Mayhew (1974b) made four decisions in creating his trend analysis. First, he calculated the percentage of the vote received as a percentage of the total major-party vote. Second, he began the focus on this issue with a primary focus on incumbent vote percentages. Third, he presented results in terms of the distribution of vote results across categories of outcomes. Fourth, he included contested and uncontested races.

Mayhew's first two decisions were quickly accepted for subsequent studies. Almost all the studies conducted since his analysis have focused on the vote as a percentage of the major party vote, and the overwhelming focus has been upon incumbents. His latter two decisions, however, were rejected, and that has had significant consequences. Rather than use the distribution of outcomes, Born argued that with the presentation of outcomes by categories, small percentage changes could result in a shift of many cases between categories and the impression of a large change. He used the average vote percentage for incumbents (Born 1979, 812-13), and almost all subsequent efforts to track the trend focused on average vote percentages or changes in them (Payne 1980, 471-72; Alford and Hibbing 1981, 1047-51; Gross and Garand 1984, 230; Garand and Gross 1984, 21; Jacobson 1987, 127; Ansolabehere et al. 2000, 24; Jacobson 2001, 24-26).

The most important decision was to exclude certain elections, usually without any explanation. Born chose to exclude all multi-member, at-large, and uncontested districts (1979: 811-12). Payne excluded multi-candidate and at-large races, and all those where a winner received more than 89 percent of the vote $(1980,469)$. The South was excluded by Alford and Hibbing $(1981,1045-46)$ and Gross and Garand $(1984,226)$ because of its "unique electoral history." Jacobson chose to focus on incumbents with major party opposition (Jacobson 1987, 126-27; 2000, 24-26).

Surprisingly, these initial decisions about how to derive this trend received no critical scrutiny. Those who did the first studies largely asserted their sense of what was appropriate, and most others replicated the focus and means of deriving vote percentages with little questioning. There is almost no evidence of dissents about these decisions. Each of these decisions, however, deserves consideration, and each affects the derived trend in vote percentages. 


\section{Assessing Decision Rules and Their Consequences}

One of the first decisions made was the simplest and is the most plausible one. Born argued that the focus should be on average percentages and not distributions. Small shifts in the average could create large shifts in distributions with 5 percentage point groupings. That point is persuasive. The next decision involves that of calculating vote percentages as a percentage of the two-party vote. This decision is less plausible. In many districts third party candidates run in the November elections. If their votes are excluded from the denominator, it reduces the vote total, and increases the apparent vote percentage of incumbents. As an example, assume a Republican wins 53 percent, a Democrat wins 40 percent, and all other candidates win seven percent of the total vote. If the third party vote is excluded, the Republican winning percentage is now $53 / 93$, or 57.0 percent. An incumbent would hardly regard a percentage of 53 as secure, and to represent the winning percentage as 57.0 is misleading. The effect of relying on the percentage of the two-party vote is to systematically inflate the apparent percentages of winning incumbents. If our concern is to track the percentage of the vote received by incumbents, it seems inappropriate to measure and present percentages that are not the actual percentages that candidates attain. In this analysis the actual percentage of the vote (based on all votes cast for candidates) is used, not the percentage of the two-party vote received.

A third issue is whether to examine the vote percentages of just incumbents or of all winners. If the concern is whether incumbents are able to use their advantage in political resources to increase their vote percentages, a focus on the former is appropriate. The analytic difficulty, however, is that if the concern is whether incumbents have some ability to affect vote percentages that non-incumbents do not have, then trends for both groups need to be examined (Collie 1981; Garand and Gross 1984, 232; Gross and Garand 1984, 26-27). If an increase in vote percentages occurs in situations with and without incumbents present, as Gross and Garand found (1984), it is questionable logic to examine just incumbents and then conclude there is a connection between incumbent political resources and changes in vote percentages.

The last decision, which elections to include, is the most important one. The decision to exclude some cases creates two serious problems of analysis. First, this means assessing a shifting number of cases over time. Second, the number of uncontested districts has a distinct trend pattern over time. The decision to exclude the uncontested races as not "meaningful" has a significant impact on the resulting trend in the vote percentages for incumbents and winners in the House. This decision is in large part the source of the trend that has received so much attention. 
The essential issue is the effect of adding in previously uncontested districts. A district that changes from being uncontested to contested rarely immediately produces a competitive district. When uncontested races are excluded, but then included when the district changes to being contested, it invariably involves adding to the average a district with a relatively high vote percentage for the incumbent or winner. The addition of the previously uncontested race, with its higher than average vote percentage, contributes to the impression that the average winning percentage is increasing. If there is a steady decline across several consecutive years in the number of uncontested races, it means adding in districts with relatively high winning percentages in a short period of time. The result is the impression of a rising average percentage, when the "real" source of change is the addition of previously uncontested districts.

The issue, then, is whether the number of uncontested races has been declining or increasing. Figure 1 indicates the number of uncontested races per year since $1946 .{ }^{3}$ Most, but not all, of these uncontested elections during the 1950s and the 1960s were in the South. If the focus is on contested races for incumbents or all winners, ${ }^{4}$ beginning in the late 1950 s there was a steady addition to the calculation of the average vote percentage of district outcomes with relatively high vote percentages.

While it appears that the exclusion and then addition of uncontested races matters, does it actually make a difference in the reported trend? And,

\section{Figure 1. Number of Incumbents Uncontested, for the Nation and by Region, 1946-2000}

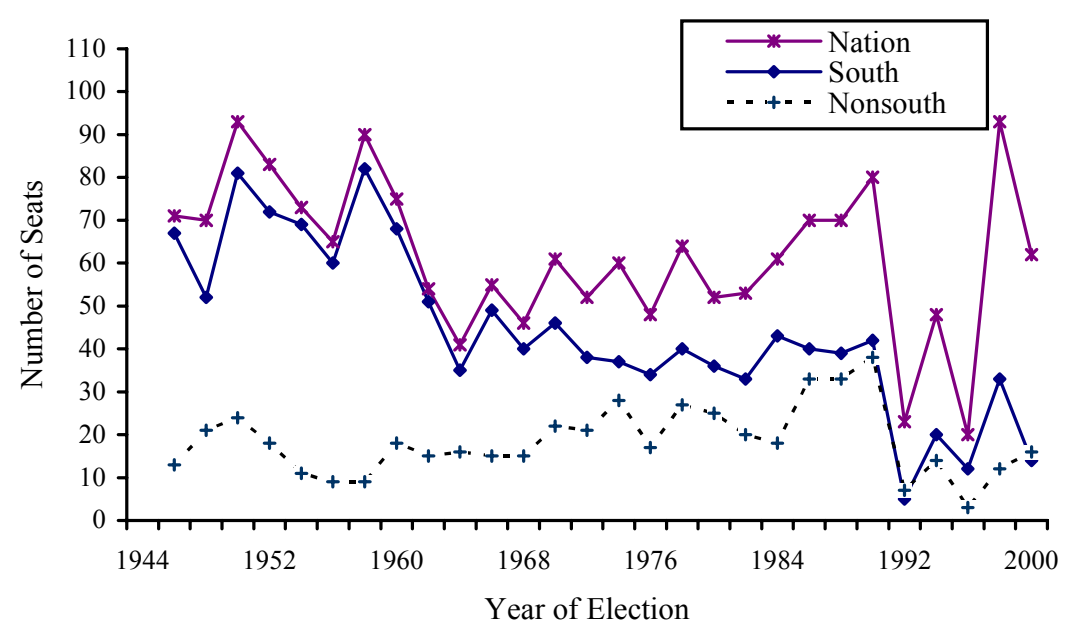


if it does make a difference, on what basis should we decide whether to include or exclude uncontested contests? Figure 2 provides the trend lines for actual vote received for contested and all incumbents. The bottom trend line represents the average vote percentage of contested incumbents, even if they lost. The top line represents the average for all incumbents running. The bottom line shows the much-discussed rising trend, and particularly for the years up to 1990. The top line shows a very different pattern. The percentages are relatively flat and within the range of 65 to 70 , except for the relatively large fluctuations that occur around 1990. It appears that which races are included has a significant impact on the trend.

To provide a more precise description of the two trends, Table 1 presents the regression of these averages on time, or the year of the election. These results indicate that the choice of contested and uncontested elections matters a great deal. If only contested incumbents are examined over the time period 1946-2000 there is a clear positive trend in averages, and time (for trend) explains a considerable proportion of the variance. If the time span is confined to the years Mayhew examined, 1956-1972, the upward trend is even more pronounced. The trend for all incumbents is very different. For both time periods there is essentially no trend, and time explains no variance. It is clear that it matters which contests are examined. The research of the last 25 years about rising incumbency vote percentages has focused on a trend that is a result of deciding to exclude uncontested districts.

Figure 2. Vote Percentage: Contested Incumbents and All Incumbents, 1946-2000

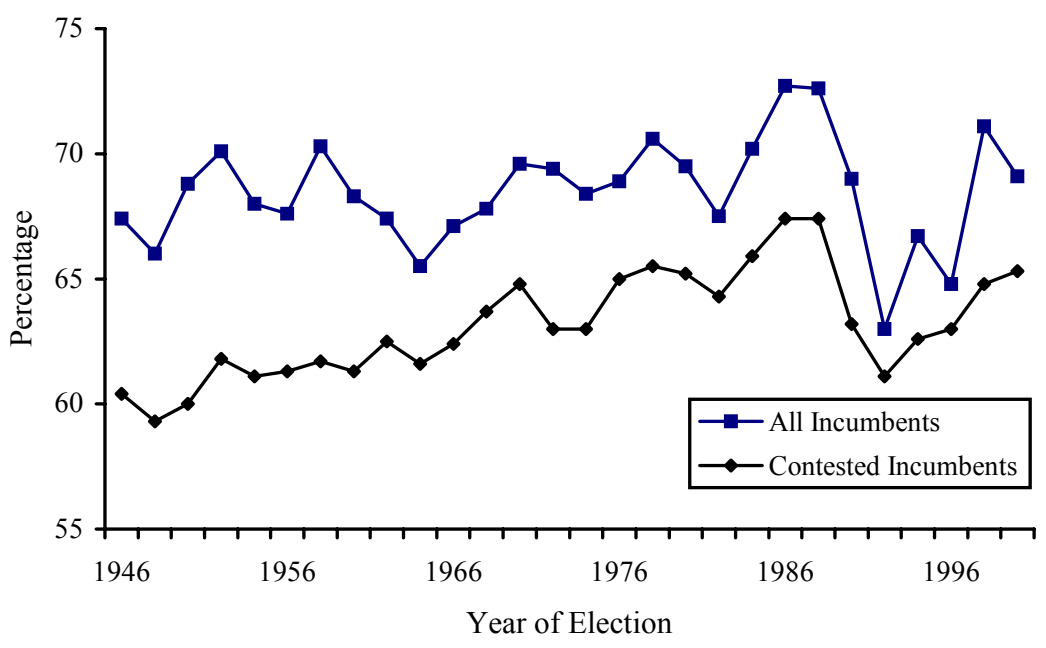


Table 1. Trend Patterns: Contested Incumbents and All Incumbents, 1946-2000

\begin{tabular}{lrrrr}
\hline & $\mathrm{n}$ & $\mathrm{B}$ & $\mathrm{r}^{2}$ & Probability \\
\hline Contested & & & & \\
$1946-2000$ & 28 & .088 & .45 & .00 \\
$1956-1972$ & 9 & .229 & .80 & .00 \\
All & & & & \\
$1946-2000$ & 28 & .014 & .01 & .58 \\
$1956-1972$ & 9 & .030 & .01 & .78 \\
Note: Entries are percentages, by column. & & & \\
\hline
\end{tabular}

The fundamental issue, then, is whether contested or all districts should be examined. There are several reasons why this exclusion is a very questionable decision. First, if the concern is tracking closeness of incumbent electoral outcomes over time, then excluding uncontested races misrepresents the average percentage of the vote received by incumbents. Given that in some years there were more than 80 uncontested elections involving incumbents, almost one-fourth of House elections involving incumbents are excluded. Second, the decision excludes districts where the parties are particularly strong, thus treating districts that lean heavily to one party as not relevant. It is an odd rule to purport to assess how incumbents are faring, while excluding those who do particularly well. If the spatial distribution of partisan populations shifts such that like-minded partisan populations cluster and become spatially segregated from each other, there will be more districts that heavily favor one party, and these districts might end up excluded from calculations. Third, it is even more questionable to set up the calculation of an average that in one year excludes a district with no opponent, and then, after an opponent appears in the next year, includes the district. The result is to add during the second year an incumbent with a relatively high percentage, which raises the average. In sum, the contested average embodies three questionable rules. It does not represent all incumbent outcomes. It excludes cases where the parties do particularly well. It also sets up a rule that, with a downward trend in uncontested races, results in a rising average that is a product of the rule and not the reality of election outcomes.

Finally, there are reasons to be skeptical of relying on a rule that results in the appearance of less competitive elections at the very time uncontested elections were declining on the national scene. From 1950 to 1964 the number of uncontested incumbent races fell from 93 to 41 . After decades of a situation in which region was a defining feature of party bases, competition 
between the parties was becoming more national in scope. Both parties were mutually contesting more districts nationally. Yet, the decision rule of excluding uncontested races led to the conclusion that competition was declining.

\section{Conclusions}

The concern of this analysis is whether there was an increase in incumbent vote margins beginning during the 1960s and continuing over the last several decades. If all incumbents are considered, there is no increase in their vote percentages over time. The attempts to explain the rise in vote percentages have all begun with the presumption that a clear trend occurred. The reason that it has been difficult to find a causal source may well be because the presumed trend does not exist. The premise of much of the subsequent research was that the electoral success of incumbents changed over time, and that premise is highly questionable.

\section{APPENDIX}

\section{Data on House Elections, 1946-2000}

\begin{tabular}{|c|c|c|c|c|c|c|c|}
\hline \multicolumn{8}{|c|}{$\begin{array}{c}\text { For Incumbents: Average Percentage of Vote Won, and Number Contested and } \\
\text { Uncontested; For All Districts: Number Uncontested and } \\
\text { Average Vote Percentages for all Winners }\end{array}$} \\
\hline \multirow[b]{3}{*}{ Year } & \multicolumn{5}{|c|}{ Incumbents } & \multicolumn{2}{|c|}{ All Districts } \\
\hline & \multicolumn{2}{|c|}{ All } & \multicolumn{2}{|c|}{ Contested } & \multirow{2}{*}{$\begin{array}{c}\text { Not } \\
\text { Contested } \\
\#\end{array}$} & \multirow{2}{*}{$\begin{array}{c}\text { Not } \\
\text { Contested } \\
\#\end{array}$} & \multirow{2}{*}{$\begin{array}{c}\text { Winners } \\
\text { Average Pct } \\
\text { All }\end{array}$} \\
\hline & $\#$ & Avg Pct & $\#$ & Avg Pct & & & \\
\hline 1946 & 380 & 67.5 & 309 & 60.4 & 71 & 80 & 68.6 \\
\hline 1948 & 388 & 66.0 & 318 & 59.3 & 70 & 76 & 67.6 \\
\hline 1950 & 400 & 68.8 & 307 & 60.0 & 93 & 95 & 69.1 \\
\hline 1952 & 369 & 70.2 & 286 & 61.8 & 83 & 91 & 69.4 \\
\hline 1954 & 400 & 68.0 & 327 & 61.1 & 73 & 79 & 68.4 \\
\hline 1956 & 403 & 67.6 & 338 & 61.3 & 65 & 67 & 67.4 \\
\hline 1958 & 391 & 70.3 & 301 & 61.7 & 90 & 92 & 69.6 \\
\hline 1960 & 402 & 68.3 & 327 & 61.3 & 75 & 77 & 68.0 \\
\hline 1962 & 376 & 67.4 & 322 & 62.5 & 54 & 54 & 66.4 \\
\hline 1964 & 393 & 65.5 & 352 & 61.6 & 41 & 42 & 65.7 \\
\hline 1966 & 403 & 67.1 & 348 & 62.4 & 55 & 57 & 67.3 \\
\hline 1968 & 397 & 67.7 & 351 & 63.9 & 46 & 47 & 67.1 \\
\hline 1970 & 393 & 69.6 & 332 & 64.5 & 61 & 61 & 68.9 \\
\hline 1972 & 375 & 69.4 & 323 & 64.8 & 52 & 54 & 68.2 \\
\hline 1974 & 382 & 68.4 & 322 & 63.0 & 60 & 60 & 68.0 \\
\hline
\end{tabular}


Appendix (continued)

\begin{tabular}{|c|c|c|c|c|c|c|c|}
\hline 1976 & 381 & 68.9 & 333 & 65.0 & 48 & 52 & 68.4 \\
\hline 1978 & 377 & 70.6 & 313 & 65.5 & 64 & 68 & 69.8 \\
\hline 1980 & 391 & 69.5 & 339 & 65.2 & 52 & 52 & 68.8 \\
\hline 1982 & 365 & 67.5 & 312 & 64.3 & 53 & 56 & 67.7 \\
\hline 1984 & 405 & 70.3 & 343 & 65.9 & 61 & 62 & 70.0 \\
\hline 1986 & 396 & 72.7 & 326 & 67.4 & 70 & 72 & 72.0 \\
\hline 1988 & 409 & 72.6 & 339 & 67.4 & 70 & 73 & 72.7 \\
\hline 1990 & 404 & 69.0 & 324 & 63.2 & 80 & 81 & 68.9 \\
\hline 1992 & 341 & 63.1 & 319 & 61.2 & 23 & 32 & 63.4 \\
\hline 1994 & 384 & 66.7 & 336 & 62.6 & 48 & 48 & 66.2 \\
\hline 1996 & 381 & 64.8 & 361 & 63.0 & 20 & 21 & 64.4 \\
\hline 1998 & 403 & 71.1 & 310 & 64.8 & 93 & 93 & 70.6 \\
\hline 2000 & 416 & 69.1 & 354 & 65.3 & 62 & 65 & 68.8 \\
\hline \multicolumn{8}{|c|}{ Averages } \\
\hline & & & & & & & \\
\hline \multirow{2}{*}{\multicolumn{2}{|c|}{$\begin{array}{l}1946-1964 \\
1966-2000\end{array}$}} & 68.0 & & 61.1 & & & 68.0 \\
\hline & & 68.8 & & 64.4 & & & 68.4 \\
\hline \multirow{2}{*}{\multicolumn{2}{|c|}{$\begin{array}{l}1956-1964 \\
1966-1972\end{array}$}} & 678 & & & & & 670 \\
\hline & & 68.5 & & 63.9 & & & 67.1 \\
\hline
\end{tabular}

\section{NOTES}

${ }^{1}$ There was also a developing interest in how much incumbency (Erikson, 1971) and redistricting (Erikson, 1972; Tufte, 1973) helped the vote percentages of House members.

${ }^{2}$ The matter of the accuracy of election results is not discussed in studies, and may not be relevant here. To the extent that analyses are based on ICPSR study 7757, however, accuracy issues are very important. I began with the data from this ICPSR study, and compared it to the election results printed in the Congressional Quarterly's Guide to U.S. Elections, Volume II, Fourth, (2001) and discovered numerous errors. I then consulted the $C Q$ Guide to try to determine what the results were for a particular district. While the $C Q$ Guide is very valuable, there are third-party candidacies that are not reported in that compilation. In some cases, the vote percentages reported appear to constitute less than $100 \%$ of all votes recorded in that contest. To try to remedy that problem, I consulted Michael J. Dubin, United States Congressional Elections, 1788-1997, (1998) to find further results.

Assuming this source is accurate, which I cannot verify, several types of errors were detected and corrected. In some cases, the percentage for the Democrat or Republican candidate was missing. In other cases a single-digit percentage was recorded for a Democrat or Republican, but that candidate actually received no votes. 
One kind of "error" is particularly noteworthy. In both California and New York, cross-endorsement of candidates has occurred, and still exists in New York. In California, a candidate might run with the endorsement of the Democratic and Republican Parties. In these cases, Dubin records the party endorsements (lines) of a candidate. I was able to verify the actual party affiliation (not endorsements) of candidates by checking their affiliation in the prior Congress, using either results for prior elections or by consulting the Congressional Biographical Guide, http://bioguide.congress.gov/biosearch/biosearch.asp. In the ICPSR data set many of these districts have no recorded votes, and these districts end up missing in analyses of vote percentages. In New York candidates can be crossendorsed and then have their name listed on both lines. I checked these cases against the official results printed in the Legislative Manual for various years. While the votes on the separate lines should be added together and recorded as only a Democratic or Republican vote, the ICPSR data set records the vote on the Democratic line as the vote for the Democratic candidate and the vote on the Republican line as the vote for a Republican candidate. The result is that a district is recorded as contested and competitive to some degree, when it was uncontested by a major party candidate. Races were recorded as closer than they were. In both of these states, I corrected the data. In California, I used Dubin or the Congressional Biographical Guide designation of the candidate's actual party affiliation, and recorded the total votes for the candidate on that party line. The other party line was given a 0 . The logic of this is that the general concern is the partisan vote for major party candidates. In each district, almost all candidates will have an initial party affiliation, and that will be known in the district. If the candidate receives the endorsement of another party, the actual vote is still for a candidate of a specific party. In New York the same logic applies. While a name is listed on two (or more lines), the party affiliation of each candidate is well-known, and the vote is for that candidate, regardless of on which line it is received.

A similar issue involves Wisconsin voting. For years the Democrat-Farmer-Labor Party served as the vehicle for representing the Democratic Party in the state. The ICPSR shows no vote for Democratic candidates in the years that the DFL was relevant. I recorded the DFL percentages as the Democratic vote. Again, the concern is not the vote percentage recorded on a party line, but the vote percentage that a candidate of a particular party received. The DFL, which operated as a fusion party, should not have no recorded vote because it is a merger of other concerns.

Results in Louisiana present a particularly difficult issue of how to record results. For some years Louisiana held an open primary in which all party candidates could enter. If no candidate received a majority, a run-off would be held between the two candidates with the highest percentages, even if they are in the same party. If a candidate did receive a majority, the individual would appear on the ballot on the traditional Tuesday in November without any apparent opposition. There would then be no recorded votes, making it difficult to record a result. If a candidate receives enough votes to avoid a runoff, the apparent result in November is 0 (no votes) or 100 percent, for no opponent. Neither option may reflect the vote proportion the candidate won in the open primary. In a study of vote percentages of members of Congress, the options of 0 or 100 percent are not satisfactory indicators of the situation the candidate faced.

These races might simply be excluded, but that also is not very satisfactory. An option is to return to the results from the United States Congressional Elections, 17881997. This presents both the open primary and runoff results. In many of these districts, several Democrats ran along with several Republicans, and the winning percentage might be, for example, only 30 percent, compared to 13 percent for a Republican. Since in this particular study the concern is the vote proportion of candidates, and their relative secur- 


\section{6 | Jeffrey M. Stonecash}

ity, the decision in this case is to record the percentages of the leading Democrat and that of the leading Republican. This is not completely satisfactory, since, the leading Democrat might receive 30 percent, followed by a Democrat with 22 percent, and then a Republican with 14 percent. Recording only the leading Democrat and Republican will underrepresent the closeness of the second highest vote recipient. That is, however, also a potential issue in a state like California where the second highest vote recipient could run on the Progressive Party, and not show up if only Democrats or Republicans are recorded. While this is a problem, it is minor because the focus in these vote records is on the proportion of winners, and the practice of recording 30 and 14 will reflect the percentage of the winner. The virtue of recording these percentages is that the winner actually received only 30 percent, which is not a secure position. Accurately recording and reflecting that low percentage seems appropriate in this case, and is what was done. If a candidate was unopposed in the open primary, the candidate is recorded as unopposed and receiving 100 percent.

The problems in California and Wisconsin may not affect results for members of Congress, if those doing data runs took care to record the vote of winners, regardless of the party lines involved. If, on the other hand, a district were recorded as having a Democratic or Republican winner, but no percentages are recorded on the Democratic or Republican line, then these districts may show up as missing in analyses. It is not possible to tell if this occurred because most studies contain no discussions of these specifics. In New York the problem could create clear errors of percentages. If a cross-endorsed Democrat in New York City has his vote across two lines, his vote proportion might be interpreted as 65 , when the actual percentage is 95 , and there is no major opponent. If only contested races are assessed, the New York situation will lead to this district being included, when it should have been excluded. Again, it is unknown whether this problem actually occurred in published studies because there is no discussion of such issues.

Finally, several decisions about the presence of an incumbent are important. If an incumbent loses the primary in his or her own party, but is still present in the November election on another line, an incumbent is recorded as present. If an incumbent switches parties, but still runs, an incumbent is recorded as present. If two incumbents run against each other, an incumbent is not recorded as present. In this case it is not possible to specify an incumbent percentage versus a challenger percentage, so no incumbent percentage is calculated. If a person was in office, and was elected in a special election within the last two years, even if only weeks or months prior to the general election, they are coded as an incumbent.

${ }^{3}$ The appendix table presents the specific data for each year on: the number of uncontested races for incumbents running for reelection and for all districts; the number of contested races for all incumbents and for all districts, and, the average vote won for each of these categories.

${ }^{4}$ Given the predominance of these races in the South, a plausible solution is to exclude the South, as some have done (Gross and Garand, 1984). The difficulty with this decision is that the South has steadily become more competitive, and excluding the South means excluding many contested districts. At some point this must stop, creating a significant disjuncture in a time series. If the trend is the object of analysis, this approach is unsatisfactory. 


\section{REFERENCES}

Abramowitz, Alan I. 1975. Name Familiarity, Reputation and the Incumbency Effect in a Congressional Election. Western Political Quarterly 28:668-684.

Abramowitz, Alan I. 1989. Campaign Spending in U.S. Senate Elections. Legislative Studies Quarterly 14:487-507.

Abramowitz, Alan I. 1991. Incumbency, Campaign Spending, and the Decline of Competition in U.S. House Elections. Journal of Politics 53:34-56.

Alford, John R. and John R. Hibbing. 1981. Increased Incumbency Advantage in the House. Journal of Politics 43:1042-1061.

Ansolabehere, Stephen, James M. Snyder, Jr., and Charles Stewart, III. 2000. Old Voters, New Voters, and the Personal Vote: Using Redistricting to Measure the Incumbency Advantage. American Journal of Political Science 44:17-34.

Born, Richard. 1979. Generational Replacement and the Growth of Incumbent Reelection Margins in the U.S. House. American Political Science Review 73:811-817.

Brady, David W., John F. Cogan, and Morris P. Fiorina. 2000. An Introduction. Pp. 1-9 in Continuity and Change in House Elections, eds. David W. Brady., John F. Cogan, and Morris P. Fiorina. Stanford, CA: Stanford University Press.

Burnham, Walter Dean. 1965. The Changing American Political Universe. The American Political Science Review 59:7-28.

Burnham, Walter Dean. 1970. Critical Elections and the Mainsprings of American Politics. New York: W.W. Norton.

Burnham, Walter Dean. 1975. Insulation and Responsiveness in Congressional Elections. Political Science Quarterly 90:411-435.

Campbell, James E. 1983. The Return of the Incumbents: The Nature of the Incumbency Advantage. Western Political Quarterly 36:434-444.

Collie, Melissa P. 1981. Incumbency, Electoral Safety, and Turnover in the House of Representatives, 1972-1976. American Political Science Review 75:119-131.

Cover, Albert. 1977. One Good Term Deserves Another: The Advantage of Incumbency in Congressional Elections. American Journal of Political Science 21:523-541.

Cover, Albert D., and David R. Mayhew. 1977. Congressional Dynamics and the Decline of Competitive Congressional Elections. Pp. 62-82 in Congress Reconsidered, eds. Lawrence C. Dodd and Bruce I. Oppenheimer. Washington, DC: CQ Press.

Cox, Gary, and Jonathan Katz. 1996. Why Did the Incumbency Advantage Grow? American Journal of Political Science 40:478-497.

Congressional Quarterly. 1994. Congressional Quarterly's Guide to U.S. Elections, 3rd ed. Washington, DC: Congressional Quarterly Press.

Converse, Philip E. 1976. The Dynamics of Party Support. Beverly Hills, CA: Sage.

Cummings, Milton C. 1966. Congressmen and the Electorate. New York: Free Press.

Dubin, Michael J. 1998. United States Congressional Elections, 1788-1997. Jefferson: McFarland and Company, Inc.

Erickson, Robert S. 1971. The Advantage of Incumbency in Congressional Elections. Polity 3:395-405.

Erickson, Robert S. 1972. Malapportionment, Gerrymandering and Party Fortunes in Congressional Elections. American Political Science Review 66:1234-1245.

Erickson, Robert S. 1976. Is There Anything Such as a Safe Seat? Polity 8:623-632.

Ferejohn, John A. 1977. On the Decline of Competition in Congressional Elections. American Political Science Review 71:166-176. 
Fiorina, Morris. 1977a. Congress: Keystone to the Washington Establishment. New Haven, CT: Yale.

Fiorina, Morris. 1977b. The Case of the Vanishing Marginals: The Bureaucracy Did It. American Political Science Review 71:177-181.

Fiorina, Morris. 1981. Some Problems in Studying the Effects of Resource Allocation in Congressional Elections. American Journal of Political Science 25:543-567.

Flanigan, William H., and Nancy H. Zingale. 1979. Political Behavior of the American Electorate. Boston: Allyn and Bacon.

Garand, James C., and Donald A. Gross. 1984. Changes in the Vote Margins for Congressional Candidates: A Specification of Historical Trends. American Political Science Review 78:17-30.

Gross, Donald A., and James C. Garand. 1984. The Vanishing Marginals, 1824-1980. Journal of Politics 46:224-237.

Jacobson, Gary C. 1978. The Effects of Campaign Spending in Congressional Elections. American Political Science Review 72:469-491.

Jacobson, Gary C. 1985. Money and Votes Reconsidered: Congressional Elections, 19721982. Public Choice 47:7-62.

Jacobson, Gary C. 1987. The Marginals Never Vanished: Incumbency and Competition in Elections to the U.S. House of Representatives, 1952-1982. American Journal of Political Science 31:126-141.

Jacobson, Gary C. 1990. The Effects of Campaign Spending in House Elections: New Evidence for an Old Argument. American Journal of Political Science 34:334-362.

Jacobson, Gary C. 1997. The Politics of Congressional Elections, 4th ed. New York: Longman.

Jacobson, Gary C. 2000. Party Polarization in National Politics: The Electoral Connection. Pp. 9-30 in Polarized Politics, ed. Jon R. Bond and Richard Fleisher. Washington, DC: CQ Press.

Jacobson, Gary C. 2001. The Politics of Congressional Elections, 5th ed. New York: Longman.

Johannes, John R., and John C. McAdams. 1981. The Congressional Incumbency Effect: Is it Casework, Policy Compatibility, or Something Else? American Journal of Political Science 25:512-542.

Jones, Charles O. 1964. Inter-Party Competition in Congressional Seats. Western Political Quarterly 17:461-476.

Krasno, Jonathon S., and Donald P. Green. 1988. Preempting Quality Challengers in House Elections. Journal of Politics 50:920-936.

Krehbiel, Keith, and John R. Wright. 1983. The Incumbency Effect in Congressional Elections: A Test of Two Explanations. American Journal of Political Science 27:140-157.

Levitt, Steven D., and Catherine D. Wolfram. 1997. Decomposing the Sources of Incumbency Advantage. Legislative Studies Quarterly 22:45-60.

Mann, Thomas E. 1978. Unsafe at Any Margin. Washington, DC: American Enterprise Institute.

Mayhew, David R. 1974a. Congressional Elections: The Case of the Vanishing Marginals. Polity 6:295-317.

Mayhew, David R. 1974b. Congress: The Electoral Connection. New Haven, CT: Yale University Press.

McAdams, John C., and John R. Johannes. 1988. Congressmen, Perquisites, and Elections. Journal of Politics 50:412-439. 
Nelson, Candice J. 1978-79. The Effect of Incumbency on Voting in Congressional Elections. Political Science Quarterly 93:665-678.

Parker, Glenn R. 1980. The Advantage of Incumbency in House Elections. American Politics Quarterly 8:449-464.

Payne, James L. 1980. The Personal Electoral Advantage of House Incumbents, 19361976. American Politics Quarterly 8:465-482.

Serra, George. 1994. What's In It for Me: The Impact of Congressional Casework on Incumbent Evaluation. American Politics Quarterly 22:403-420.

Serra, George, and Albert D. Cover. 1992. The Electoral Consequences of Perquisite Use: The Casework Case. Legislative Studies Quarterly 17:233-246.

Thomas, Scott J. 1989. Do Incumbent Campaign Expenditures Matter? Journal of Politics 51:965-976.

Tufte, Edward R. 1973. The Relationship between Seats and Votes in Two-Party Systems. American Political Science Review 67:540-554.

Yiannakis, Diana Evans. 1981. The Grateful Electorate: Casework and Congressional Elections. American Journal of Political Science 25:568-580. 
